\title{
Terrane Boundary Geophysical Signatures in Northwest Panay, Philippines: Results from Gravity, Seismic Refraction and Electrical Resistivity Investigations
}

\author{
Jillian Aira S. Gabo ${ }^{1,2, *}$, Carla B. Dimalanta ${ }^{1}$, Graciano P. Yumul Jr. ${ }^{3}$, Decibel V. Faustino-Eslava ${ }^{4}$, and \\ Akira Imai ${ }^{2,5}$ \\ ${ }^{1}$ Rushurgent Working Group, National Institute of Geological Sciences, College of Science, University of the Philippines, Quezon \\ City, Philippines \\ ${ }^{2}$ Research Institute of Environment for Sustainability, Faculty of Engineering, Kyushu University, Fukuoka, Japan \\ ${ }^{3}$ Apex Mining Company Inc., Ortigas City, Philippines \\ ${ }^{4}$ School of Environmental Science and Management, University of the Philippines, Laguna, Philippines \\ ${ }^{5}$ Department of Earth Science and Technology, Faculty of Engineering and Resource Science, Akita University, Akita, Japan
}

Received 12 February 2013, revised 11 September 2014, accepted 11 May 2015

\begin{abstract}
Northwest Panay consists of two terranes that form part of the Central Philippine collision zone: Buruanga Peninsula and Antique Range. The Buruanga Peninsula consists of a Jurassic chert-clastic-limestone sequence, typical of oceanic plate stratigraphy of the Palawan Micro-continental Block. The Antique Range is characterized by Antique Ophiolite Complex peridotites and Miocene volcanic and clastic rocks, representing obducted oceanic crust that serves as the oceanic leading edge of the collision with the Philippine Mobile Belt. The Nabas Fault is identified as the boundary between the two terranes. This study employed the gravity method to characterize the Northwest Panay subsurface structure. Results indicate higher Bouguer anomaly values for Buruanga Peninsula than those for Antique Range, separated by a sudden decrease in gravity values toward the east-southeast (ESE) direction. Forward gravity data modeling indicates the presence of an underlying basaltic subducted slab in the Buruanga Peninsula. Furthermore, the Nabas Fault is characterized as an east-dipping thrust structure formed by Buruanga Peninsula basement leading edge subduction beneath Antique Range. Additional geophysical constraints were provided by shallow seismic refraction and electrical resistivity surveys. Results from both methods delineated the shallow subsurface signature of the Nabas Fault buried beneath alluvium deposits. The gravity, seismic refraction and electrical resistivity methods were consistent in identifying the Nabas Fault as the terrane boundary between the Buruanga Peninsula and the Antique Range. The three geophysical methods helped constrain the subsurface configuration in Northwest Panay.
\end{abstract}

Key words: Northwest Panay, Arc-continent collision, Terrane boundary, Gravity modeling, Geophysical signature, Central Philippines Citation: Gabo, J. A. S., C. B. Dimalanta, G. P. Yumul Jr., D. V. Faustino-Eslava, and A. Imai, 2015: Terrane boundary geophysical signatures in Northwest Panay, Philippines: Results from gravity, seismic refraction and electrical resistivity investigations. Terr. Atmos. Ocean. Sci., 26, 663-678, doi: 10.3319/ TAO.2015.05.11.03(TC)

\section{INTRODUCTION}

Arc-continent collision processes usually result in crustal-growth processes such as arc magmatism, ophiolite emplacement, terrane accretion and suturing (Condie 1997; Dimalanta and Yumul 2004; English and Johnston 2005). In addition, the participation of oceanic bathymetric highs (e.g., seamounts, spreading ridge, micro-continental blocks) contributes to the significant geologic features observed in

\footnotetext{
* Corresponding author

E-mail: jillian-g@mine.kyushu-u.ac.jp
}

combined subduction-collision zones (Pubellier and Cobbold 1996; Bautista et al. 2001; Meffre and Crawford 2001; Yumul et al. 2005; Scalabrino et al. 2011). The collision between the Palawan Micro-continental Block and the Philippine Mobile Belt is one of the most significant geological events in the tectonic history of the Philippines. The collision boundary runs from east of Mindoro, east of the Romblon Island Group and across Panay Island in the Central Philippines (McCabe et al. 1985; Yumul et al. 2003). Similar to arc-continent collision zone features in the Western Pacific 
(e.g., Aitchison et al. 1995; Byrne and Liu 2002; Brown et al. 2006; Yumul et al. 2009), the Central Philippines consists of distinct oceanic, continental and ophiolitic terranes (McCabe et al. 1985; Zamoras et al. 2008). In a collisionrelated tectonic setting such as the Central Philippines, the geophysical signatures may include large positive gravity, resistivity and velocity anomalies for ophiolitic bodies and oceanic bathymetric highs and also lower gravity, resistivity and velocity anomalies from structures related to the collision (Hayes and Lewis 1984; Besana et al. 1997; Franco and Abbott 1999; Dimalanta and Yumul 2004).

The collision features are preserved in Northwest Panay, where the Buruanga Peninsula and the Antique Range terranes are located (Fig. 1). In the study area the Nabas Fault at the neck of the Buruanga Peninsula serves as the boundary between the two terranes (McCabe et al. 1982; Zamoras et al. 2008). However, no surface manifestation of this tectonic feature was observed since the fault zone is covered by alluvial deposits (Francisco 1956; Zamoras et al. 2008).

With this reality, it was believed that geophysical surveys can unravel things not readily recognized by field mapping. Geophysical techniques have proven useful in providing subsurface models, particularly when surface mapping alone is insufficient to provide a complete geological picture. Subsurface modeling is especially valuable in delineating subsurface features that may play important roles in the tectonic history of a region. The gravity method is one of the oldest geophysical tools (Telford 1976; Best and Boniwell 1989) that can provide an image of the subsurface structure and delineate the presence of significant features (Louis et al. 2002; Wang et al. 2005; Ganerød et al. 2006). The gravity method has been used to model the subsurface configuration of terrane boundaries (e.g., King and Barr 2004) and collision zones (e.g., Chi et al. 2003; White et al. 2005; Eaton and Darbyshire 2010). In addition to the gravity method, another useful geophysical method for detecting buried structures is shallow seismic refraction. Although larger-scale seismic refraction surveys with much deeper penetration capabilities are used to determine crustal structures in different tectonic settings, the shallow seismic refraction method can detect changes in the velocities of shallow subsurface materials and can map lower velocity features such as faults (Louis et al. 2002; Zhigulev and Patrikeev 2007). The seismic refraction method was employed to confirm the presence of faults that were identified by geological mapping akin to what has been done in other similarly-situated areas (Yan et al. 2005). The electrical resistivity method is also a useful geophysical method in the detection of structures (Suresh et al. 1992; Seaton and Burbey 2002; Adepelumi et al. 2006). This method is usually paired alongside other geophysical methods to detect buried faults (Sharma and Baranwal 2005; Dutta et al. 2006).

The Central Philippines collision is one of the most investigated aspects of Philippine geology. However, very few studies focused on geophysical techniques to characterize the collision zone. Northwest Panay was investigated to identify collision features preserved in this area and look into the geophysical aspect of studying this significant collision event. This study employed the gravity method to identify larger-scale tectonic features in different tectonic settings and provide a subsurface image of the area affected by the collision between the Palawan Micro-continental Block and the Philippine Mobile Belt. The seismic refraction and electrical resistivity methods were conducted to provide additional geophysical constraints especially on the shallow subsurface structures of the Nabas Fault, the perceived terrane boundary in Northwest Panay.

\section{GEOLOGICAL SETTING}

The Philippine archipelago is a complex island arc system located between the Philippine Sea Plate and the Sundaland-Eurasian Plate (Fig. 1). The western portion is bounded by the discontinuous east-dipping Manila-NegrosSulu-Cotabato trench system. To the east, it is bounded by the East Luzon Trough-Philippine Trench system (Taylor and Hayes 1980; Aurelio et al. 1991). The Pliocene Philippine Fault Zone, a sinistral strike-slip fault, cuts across the archipelago to accommodate the lateral component of the oblique convergence between the Philippine Sea Plate and Philippine Mobile Belt (Barrier et al. 1991; Aurelio 2000). In the west-central portion of the archipelago, where Northwest Panay is located, features of the collision between the Palawan Micro-continental Block and the Philippine Mobile Belt collision are preserved (Condie 1997; English and Johnston 2005; Yumul et al. 2005, 2009).

The Palawan Micro-continental Block is part of the Mesozoic East Asian accretionary complex that was rifted from the Eurasian Mainland and translated southeastward during the Oligocene opening of the South China Sea (Holloway 1982; Hsu et al. 2004; Zamoras and Matsuoka 2004; Zamoras et al. 2008). This southeastward translation of the Palawan Micro-continental Block resulted in its collision with the Philippine Mobile Belt during the Miocene period (McCabe et al. 1985; Sarewitz and Karig 1986; Yumul et al. 2003, 2005; Zamoras et al. 2008).

The study area is Northwest Panay, including Buruanga Peninsula and Antique Range, which is considered as the southeastern boundary of the Central Philippines collision (Rangin et al. 1989; Tamayo et al. 2001; Zamoras et al. 2008; Yumul et al. 2009). Two distinct terranes comprise Northwest Panay: the Buruanga Peninsula and the northern part of the Antique Range (Mines and Geosciences Bureau 2004; Zamoras et al. 2008; Gabo et al. 2009) (Fig. 2). The Buruanga Peninsula and the Antique Range were recognized to be part of the Mindoro-Panay Disrupt terrane, a heterogeneous mixed terrane produced from the collision (McCabe et al. 1985). 
The Buruanga Peninsula dominantly consists of Middle to Late Jurassic chert-clastic-limestone sequences underlain by a basaltic basement and intruded by the Early Miocene Patria Quartz Diorite (Zamoras et al. 2008; Gabo et al. 2009) (Fig. 2). This lithology is characteristic of an oceanic plate stratigraphic sequence typically found in oceanic plates that are accumulating sediments while traveling to the subduction zone (Wakita and Metcalfe 2005). The thinly bedded, highly jointed and intensely folded chert sequences belong to the early Middle Jurassic Unidos Formation (Zamoras et al. 2008). This rock unit can be observed in the north-central portion of the peninsula. The apparent thickness of the formation is $1500 \mathrm{~m}$. alternating with the Unidos Formation cherts, clastic rocks of the Saboncogon Formation. It is composed of siliceous mudstone and interbeds of terrigenous mudstone and sandstone. The siliceous mudstone serves as the base of the unit and conformably overlies the Middle Jurassic to early Late Jurassic Unidos Formation cherts (Zamoras et al. 2008). Overlying the siliceous mudstone are interbeds of terrigenous mudstone, shale and sandstone. The clastic rocks are

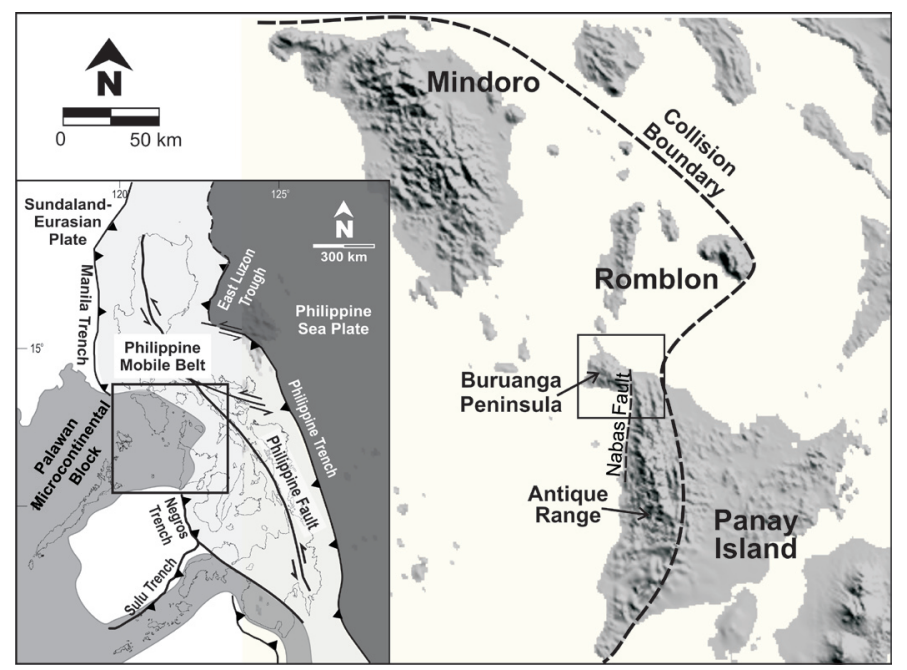

Fig. 1. Tectonic setting of Central Philippines (modified from Yumul et al. 2005). Inset shows the Philippine archipelago with the boxed area showing the location of Central Philippines.

(a)

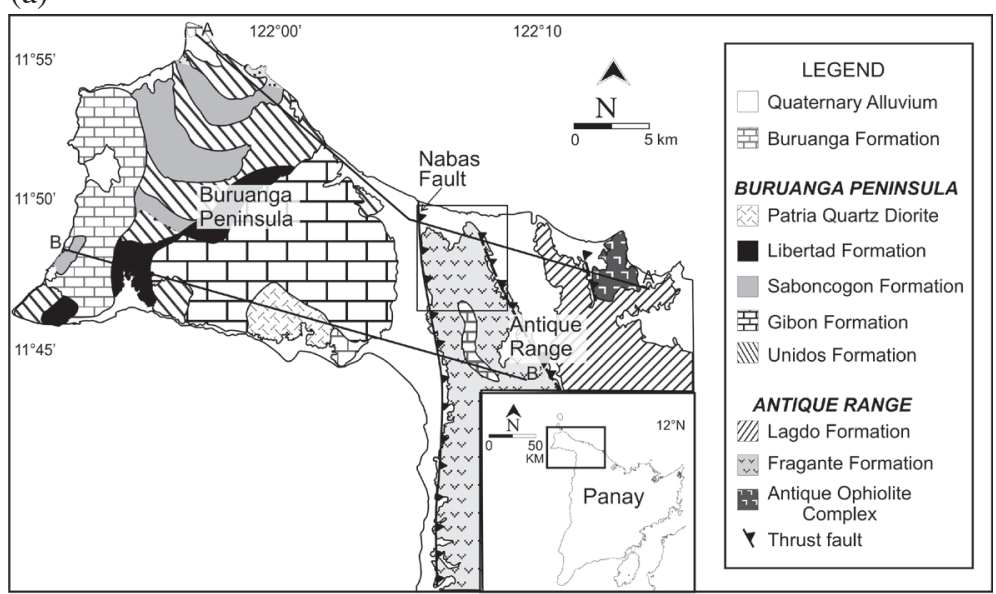

(b)

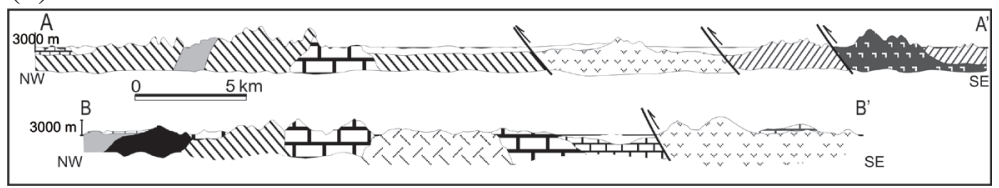

Fig. 2. Geology of the study area. (a) Geological map of Northwest Panay. The boxed area is the location of shallow seismic refraction and electrical resistivity surveys shown in Fig. 7a. (b) Cross-sections indicate the relationships of the rock formations. The profile A - A' is used for the gravity profile in Fig. 5b. 
composed of lithic fragments, quartz, feldspars, clay and organic matter. Geochemical signatures of the sandstones suggest a silicic source and a continental margin setting (Gabo et al. 2009). The approximate thickness of the formation is $1500-2000 \mathrm{~m}$ based on cross-sections. In the southerncentral portion of the Buruanga Peninsula the Gibon Formation limestone is intercalated with Unidos Formation cherts. The Gibon Formation is characterized by well-indurated to highly fractured pelagic limestone. This formation might be syndepositional with the early Middle Jurassic Unidos Formation based on the observed inter-tonguing relationship observed in several areas. The Buruanga Metamorphics is a 2-km wide, southwest-northeast trending zone located at the boundary between the Unidos-Saboncogon Formations and the Gibon Formation. It consists of slate, phyllite and quartz-sericite schist. All the metamorphic rocks have a similar quartz, muscovite and biotite composition. In the south-central portion of the Buruanga Peninsula, the Patria Quartz Diorite intruded the Gibon Formation limestone. The Patria Quartz Diorite has an age of $20.8 \pm 1$ Ma from wholerock and 19.5 \pm 1 Ma from biotite mineral separates (Rangin and Silver 1991). This age was confirmed by ${ }^{40} \mathrm{Ar} /{ }^{39} \mathrm{Ar}$ ages of $18.52 \pm 0.06$ and $18.71 \pm 0.05 \mathrm{Ma}$ from biotite separates (Walia et al. 2013). Small highly weathered basaltic rock exposures are also present in the Buruanga Peninsula, although they are too small to be mappable. They are found unconformably overlain by Unidos Formation cherts or Gibon Formation limestone in the southern portion of the peninsula neck. The observed basalt outcrops were highly chloritized, weathered and vegetated. The Buruanga Peninsula exhibits facies changes from an oceanic plate from a pelagic environment (cherts of the Unidos Formation) traveling towards the subduction zone (siliceous mudstone of the Saboncogon Formation) to the continental margin (quartz-rich sandstone of the Saboncogon Formation) (Zamoras et al. 2008).

The portion of the Antique Range investigated in this study is composed of peridotites from the Late Cretaceous Antique Ophiolite Complex (Rangin et al. 1991; Tamayo et al. 2001), the volcanic and clastic rocks of the Fragante Formation and sedimentary rocks of the late Middle Miocene Lagdo Formation (Fig. 2). The northeastern portion of the study area consists of ultramafic rocks from the Antique Ophiolite complex. The rocks are classified as serpentinized dunites, harzburgites and lherzolites. The ultramafic unit is thrust over the Lagdo Formation. The Antique Ophiolite Complex represents obducted oceanic crust emplaced in Panay Island during this Miocene collision (Tamayo et al. 2001; Yumul et al. 2009). In the northwestern portion of the Antique Range is the Middle Miocene Fragante Formation (Zamoras et al. 2008). It is characterized by volcaniclastic deposits and andesitic lava flow deposits overlain by conglomerates that are interbed with sandstone and minor patches of limestone. The geochemical signatures of volcanic rocks from the Fragante Formation suggests an origin from either two or more tectonic environments of varying origin, or a single tectonic environment that has undergone multiple and varying stages of magmatism (Gabo 2009). Some volcanic rocks from the Fragante Formation imply mid-oceanic ridge basalt (MORB) environment, but other samples indicate ocean island basalt (OIB) signature (Gabo 2009). Overlying the volcanic deposits are alternating beds of conglomerate and sandstone. The conglomerate consists of pebble- to cobble-sized, subrounded to rounded clasts of chert, schist, limestone, andesite, and basalt in sand-sized matrix. The sandstone is classified as lithic greywacke to litharenites, being dominantly composed of lithic fragments with feldspar and occasional quartz. The sandstone geochemistry indicates both mafic and silicic sources for the Fragante Formation (Gabo et al. 2009). The Fragante Formation limestone occurs as isolated hills in the central and southeastern parts of the formation. The estimated formation thickness is $200 \mathrm{~m}$ based on cross-sections. The late Middle Miocene Lagdo Formation is found in the eastern portion of the study area (Mines and Geosciences Bureau 2004). This formation is composed of clastic rocks such as sandstone, conglomerate, mudstone and shale. The sandstone facies of the Lagdo Formation are characterized by alternating medium to thick beds of red and green mediumgrained lithic sandstone. Sandstone geochemical analysis suggests deposition in an oceanic island arc setting with a mafic provenance (Gabo et al. 2009). The sandstones are unconformably overlain by poorly sorted conglomerates consisting of peridotite clasts. Unconformably overlying the conglomerate are interbeds of mudstone, shale and sandstone. The sandstone is classified as a litharenite, consisting dominantly of lithic fragments, some feldspar and very little quartz. The average thickness of the formation is $500 \mathrm{~m}$ (Abadilla 1931). The Antique Range was identified as a part of the suture zone resulting from the Miocene collision of the Palawan Micro-continental Block and the Philippine Mobile Belt (Tamayo et al. 2001).

Found on both terranes are the Plio-Pleistocene sedimentary units of the Libertad Formation (Zamoras et al. 2008). In the Buruanga Peninsula, the formation occurs in the western portion, unconformably overlying the Saboncogon Formation (Fig. 2). It is found capping the Fragante Formation in the Antique Range. The Libertad Formation is characterized by calcareous units composed of coralline limestone with an underlying minor unit of calcareous sandstone-mudstone. Based on cross-sections, the estimated thickness of the Libertad Formation is $150 \mathrm{~m}$. This formation serves as sedimentary capping to both the Buruanga Peninsula and the Antique Range terranes. A more detailed discussion of the Northwest Panay geology is provided in Zamoras et al. (2008).

The Nabas Fault is a structure covered by alluvial deposits in the eastern boundary of the valley between the Buruanga Peninsula and the Antique Range (Fig. 2). The 
Nabas Fault was first delineated based on differences in the age, rock types and geochemical composition of the sedimentary packages found in the Buruanga Peninsula and the Antique Range (Zamoras et al. 2008; Gabo et al. 2009). It is considered the boundary between the two terranes (Zamoras et al. 2008). A dominantly shallow $(0-65 \mathrm{~km})$ earthquake occurrence for the Nabas Fault (Fig. 3) is revealed by seismicity data collected by Ramos et al. (2005) from 1907 - 2003 as recorded by the Southeast Asia Association of Seismology and Earthquake Engineering (SEASEE) Bulletins and the Philippine Institute of Volcanology and Seismology database (PHIVOLCS). When the deeper crust is examined the number of earthquakes becomes sparser for Panay Island, similar to the case of Mindoro Island and the Romblon Island Group. The sparse earthquake events in the Central Philippines indicate that the Palawan Microcontinental Block indentation to the Philippine Mobile Belt caused Manila Trench subduction termination in this region (Bautista et al. 2001). The lack of intermediate to deep hypocenters in the Central Philippines can be attributed to the more buoyant nature of the Palawan Micro-continental Block (Ramos et al. 2005). The focal mechanism solutions of more recent earthquakes display the maximum horizontal compressive stress orientations from the World Stress Map database (Heidbach et al. 2008) indicating thrust and strikeslip motions for earthquakes near the study area (Fig. 4).

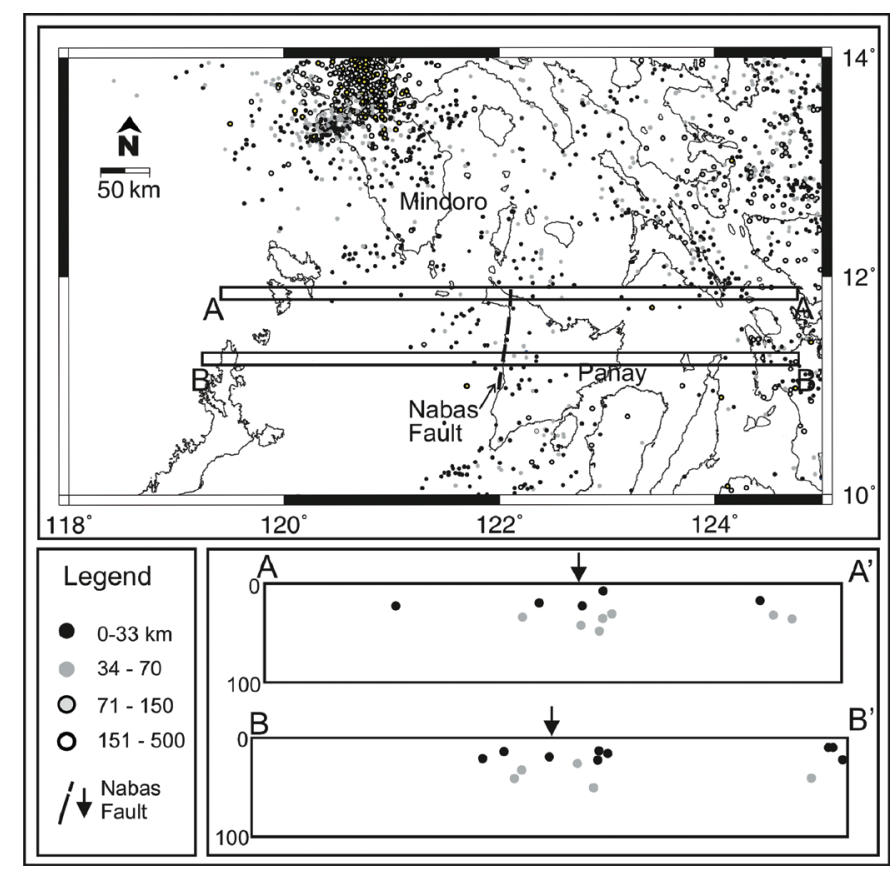

Fig. 3. Seismicity data for the Central Philippines from Ramos et al. (2005) showing earthquake hypocenters from seismic events from 1907 - 2003.

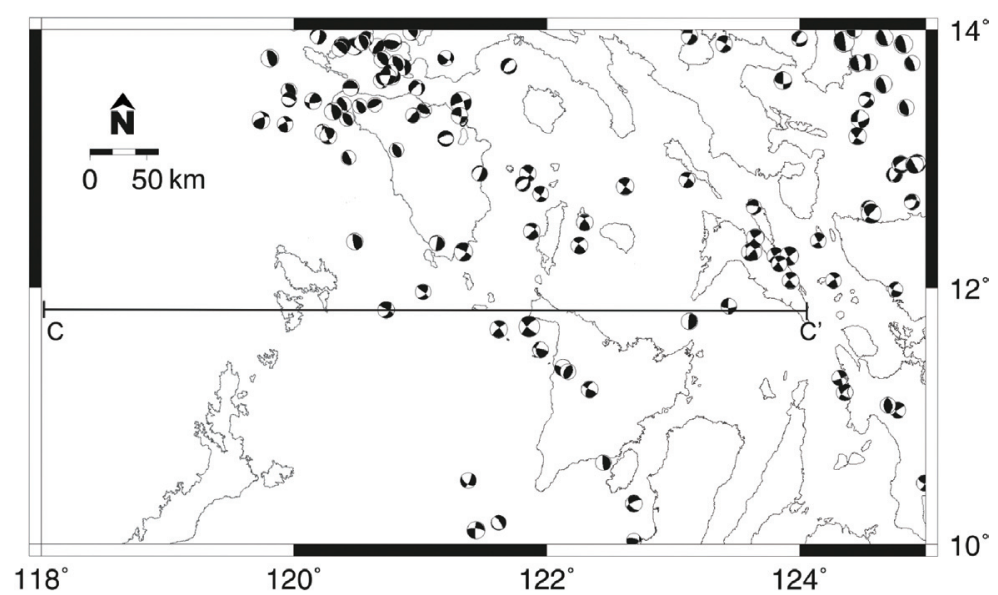

Fig. 4. Focal mechanism solutions from past earthquakes in Northwest Panay (from World Stress Map database, Heidbach et al. 2008). The line marked C - C' shows the location of the profile in Fig. 9. 
There are no solutions observed for the Nabas Fault, an indication that the structure is inactive. The Nabas Fault is considered an onshore segment of the once-continuous Manila Trench (Yumul et al. 2005; Zamoras et al. 2008). Following the Manila Trench trend, the Nabas Fault is interpreted to be an east-dipping, west-verging thrust fault (JICA-MMAJ 1988; Zamoras et al. 2008).

\section{GEOPHYSICAL METHODS}

\subsection{Gravity}

The gravity method was employed in the study area to identify subsurface features that might provide constraints to the Northwest Panay geological setting. A ScintrexCG5 Autograv gravity meter (0.001 mGal resolution) was utilized to gather gravity data. The collected gravity data represents the local gravity values in Northwest Panay and not the absolute gravity values as determined by the Bureau Gravimetrique Internationale. The nearest reference station (Gravity station: 036981) was located in the old Iloilo City airport terminal building on Panay Island, $150 \mathrm{~km}$ away from the study area. The airport buildings were demolished and replaced with new infrastructure so the original location for the reference station could not be determined. The main base station used for this survey is the Provincial Engineer's Office in Ibajay, Aklan (11 $\left.{ }^{\circ} 48^{\prime} 48.9^{\prime \prime} \mathrm{N}, 122^{\circ} 09^{\prime} 10.8^{\prime \prime} \mathrm{E}\right)$.
A grid anomaly map was originally planned for the study area. However, problems with accessibility limited the survey to roads and trails. There were 111 survey stations that were occupied at about one-kilometer intervals (Fig. 5a). Three gravity readings were taken for each survey station. The GPS location, time of measurement and topographic highs and lows were also noted. The elevation of each gravity station was determined using a micro-altimeter, calibrated using established benchmarks from the Philippine Department of Public Works and Highways. Base stations were reoccupied approximately every two hours to check for instrument drift. To provide additional modeling constraints, representative rock samples from each lithology were collected and their density values determined using the water displacement method.

The collected gravity data were subjected to several corrections in order to remove the effects of factors other than the mass distribution in the Earth local to the survey area (Best and Boniwell 1989). These corrections included drift, terrane, latitude, free-air and Bouguer. The Geosoft Oasis Montaj program was used to process the collected gravity data and apply the necessary corrections. Drift correction was applied to remove the time-dependent variation effect in gravity readings. To account for this, base stations were periodically reoccupied and the differences in the reading values were linearly distributed. In selected areas with extreme

(a)

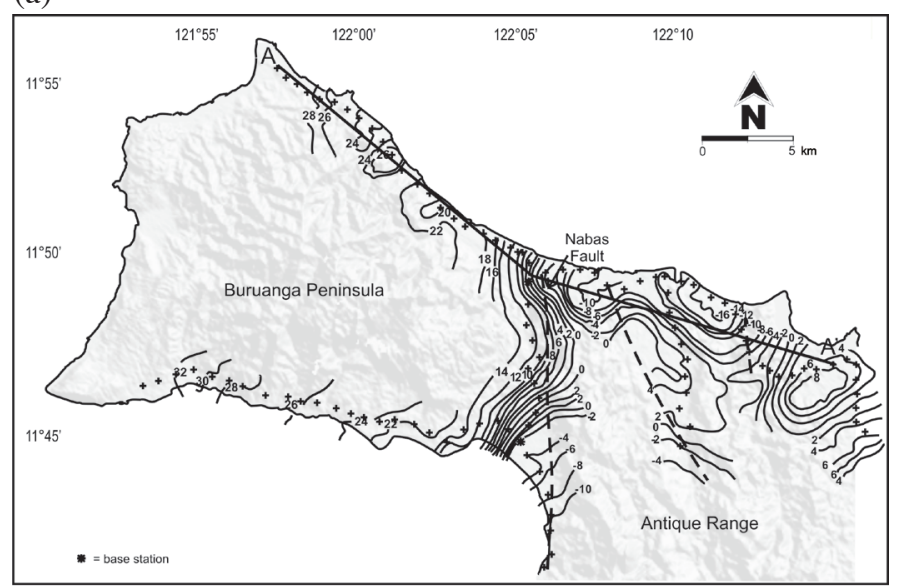

(b)

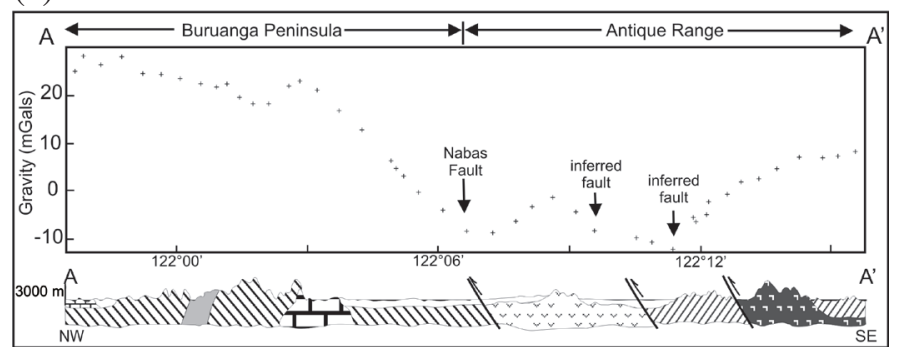

Fig. 5. The gravity survey results. (a) Bouguer anomaly values for the gravity stations occupied in the Northwest Panay. (b) A profile of the Bouguer anomaly values extracted from the northern portion of the study area (profile A - A' in Fig. 2) with the corresponding geological cross-section provided for comparison. 
topographic irregularities, terrane correction was calculated using a program OuterTC (2009), a traditional (freeware) terrane correction program utilizing Shuttle Radar Topography Mission (SRTM) elevation data. The latitude and freeair corrections were applied to produce the free-air anomaly. The Bouguer correction ( $\rho=2670 \mathrm{~kg} \mathrm{~m}^{-3}$ ) was in turn applied to the free-air anomaly to account for the topographic mass effect between the level of each gravity station and the mean sea level. The resulting Bouguer anomaly values were then gridded using the Kriging interpolation method, with a grid interval of $0.5 \mathrm{~km}$. The Kriging technique was selected over other statistical procedures because it incorporates data spatial correlation (Largueche 2006). This method is compatible with close-range areas such as Northwest Panay. Another advantage of Kriging over other contouring techniques is its ability to quantify the estimation variance, which will help define the precision of the resulting estimates (Largueche 2006). The method used the limited data available to describe the real conditions as precisely as possible. The Bouguer anomaly map thus drawn for Northwest Panay is shown in Fig. 5a.

Forward gravity data modeling was conducted to correlate the gravity signatures with the mapped lithologies, to produce a model of the subsurface and determine the configuration of buried tectonic features. The Geosoft GM-SYS profile modeling software was used in forward modeling. Although the nature of this method produces non-unique subsurface models, geological data from field mapping provided the constraint for the interpretation. Since the gravity survey points were limited to roads and trails due to accessibility problems in the mountainous regions, there were limited profiles that could be used for modeling. The E - W profile in the northern portion was chosen because the profile encountered almost all of the lithologies mapped in the area. A twodimensional gravity data model was prepared from the linear set-up. Polygons were created to represent the subsurface configuration based on the geological cross-section. Each polygon was assigned a corresponding density value based on existing literature density values and the measured values of representative rock samples. The polygon configuration produced a calculated gravity value. The polygons were adjusted until good correlation between the observed and calculated values was achieved. Considering the local extent of the gravity survey conducted, the depth of the model produced was constrained to a shallow $(4 \mathrm{~km})$ depth.

\subsection{Seismic Refraction}

Since the Nabas Fault was identified by geological data to be a buried structure underneath alluvial sediments, the study utilized the shallow seismic refraction method to help constrain the near-surface geophysical signature of the Nabas Fault.

Data were gathered using a PASI 12S12L seismo- graph with a nominal penetration depth of $60 \mathrm{~m}$. The survey spread orientation was made perpendicular to the Nabas Fault strike to detect any subsurface heterogeneity caused by the structure. Survey lines were located in relatively flat areas and as far as possible away from major roads that may become sources of geophysical noise (i.e., electrical lines, vehicles). The survey line locations were determined using a handheld Geographic Positioning System whereas the line orientations were taken using a Brunton-type compass. Each seismic spread consisted of geophones that were spaced five meters apart, which provided the greatest distance that can be covered by the instrument without sacrificing the resolution produced. A hammer striking a metal plate was used as the energy source for the survey. Stacking was applied by executing multiple strikes to increase the signal to noise ratio. Offset shots, end shots and center shots were fired at different portions of the seismic spread (Fig. 6a). The length of the seismic spread was increased by complex acquisition, where the center shot location of the former spread is used as the offset shot location of the subsequent spread, and so on. After each shot was fired the geophones detected the seismic signal from the subsurface and the arrival times of the returning waves were recorded in the seismograph.

Seismic refraction data filtering was applied to reduce the noise effects and increase the signal to noise ratio. Depending on the amount of background noise, either a highcut filter $(588 \mathrm{~Hz})$ or low-cut filter $(58 \mathrm{~Hz})$ was applied. The WGeosoft WinSism 10.4 software was used for data processing. After filtering the first arrival times of the refracted waves were picked or selected (Fig. 6b). The first breaks were plotted as a function of the geophone and shot positions in the spread to produce a time-distance assembly. The intercept times calculated from the time-distance assembly were used to identify the number of layers present, to calculate for the velocity of each layer and determine the depth and thickness of the layers. The final calculation output is a subsurface velocity profile.

\subsection{Electrical Resistivity}

The electrical resistivity method was employed to provide additional constraint for the geophysical investigation of the near-surface Nahas Fault geophysical signature. The survey sounding points were placed alongside the seismic refraction survey spreads to provide effective control on the geophysical data of the shallow subsurface (Fig. 7a). A Geometrics GEOTRADE-GTR3 resistivity meter was used to measure apparent resistivity values. The resistivity setup used the Schlumberger array, where a symmetrical distribution of the current (A and B) and potential (M and N) electrodes are set up about a central point (Milsom 1996). The distance between the current electrodes placed on the ground was increased as succeeding measurements were taken. The spacing of the potential electrodes was adjusted less 
(a)

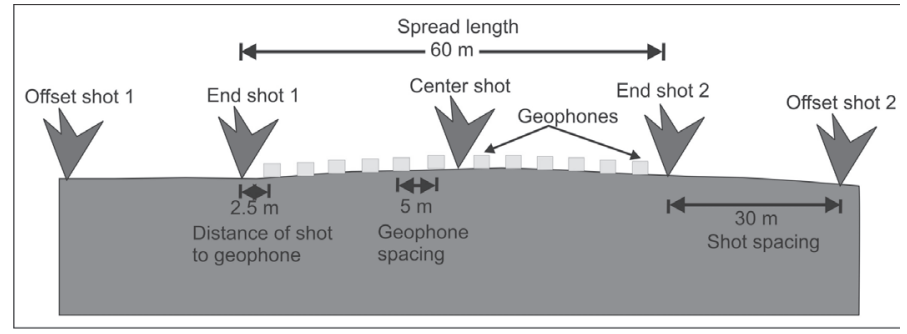

(b)

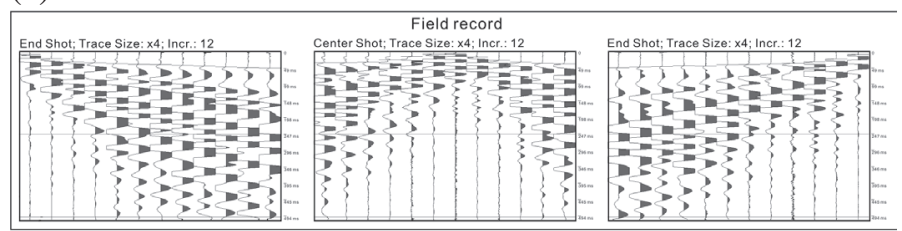

(c)

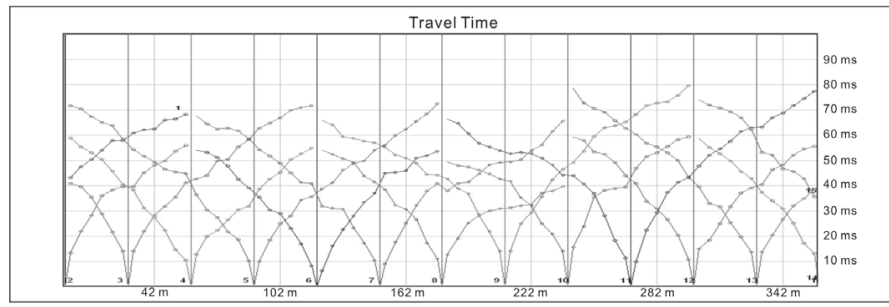

Fig. 6. Seismic refraction acquisition and processing. (a) The field geometry of the seismic refraction survey used for the study. (b) Examples of the first arrival times of the refracted waves from the shots fired.

(a)

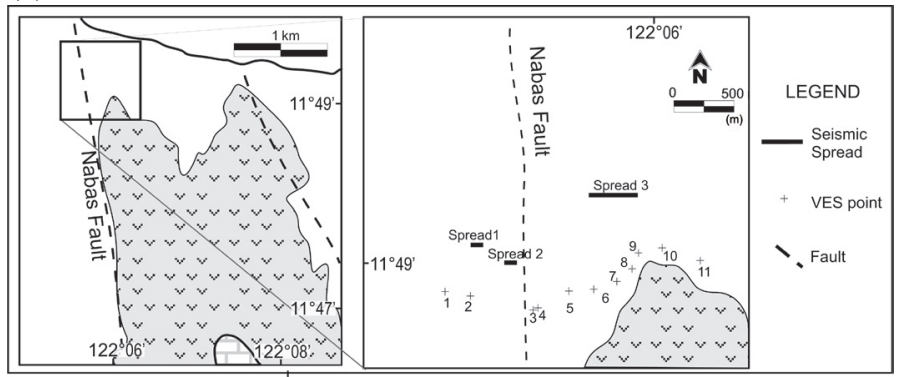

(b)

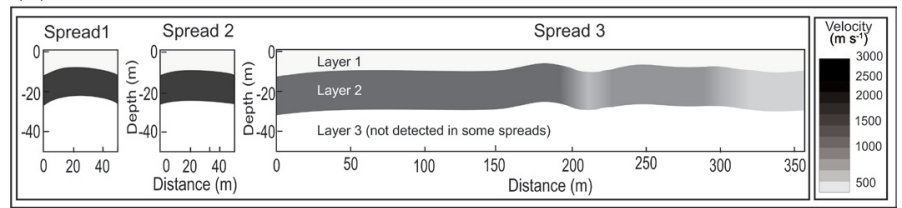

(c)

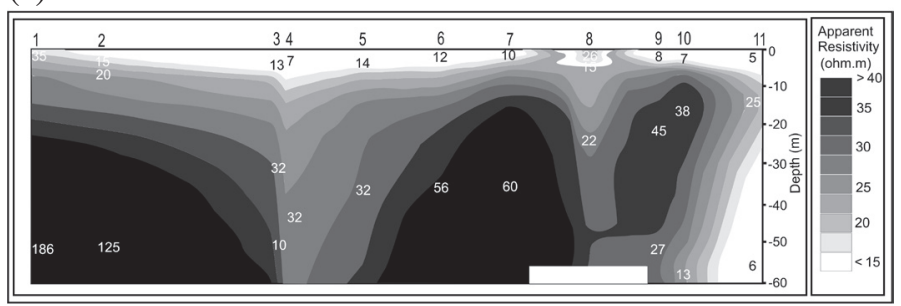

Fig. 7. Shallow seismic refraction and electrical resistivity survey results. (a) Location map of the shallow seismic refraction and electrical resistivity methods. The area represents the boxed part of Fig. 2a. (b) Results of the seismic survey in Northwest Panay. (c) Subsurface profile from apparent resistivity values of the Vertical electrical sounding (VES) stations. 
frequently. The distance between the electrodes was set farther and farther apart as greater penetration depth was desired. For this survey, electrodes A and B were spaced to a maximum distance of $300 \mathrm{~m}$ to reach a penetration depth down to $60 \mathrm{~m}$. The current (I) from the source was introduced into the ground through the $\mathrm{AB}$ electrodes and the potential difference $(V)$ resulting from the electrical resistivity variations in the subsurface passed through the MN electrodes, which was recorded by the resistivity meter (Table 1 ).

The Geosoft WinSev 6.1 interpretation software was utilized to generate a theoretical resistivity curve. Data processing and inverse modeling techniques followed those of Armada et al. (2009). Inverse theoretical curve modeling yielded a vertical subsurface model for the sounding point (Vertical electrical sounding points, VES). Geologic mapping information was used to constrain the sounding model. The VES points were combined as a geoelectric section to assess vertical as well as lateral changes in resistivity values.

\section{RESULTS}

\subsection{Gravity}

The resulting Bouguer anomaly map is shown in Fig. 5a. The Bouguer anomaly values in the Buruanga Peninsula, representing the oceanic plate stratigraphy, range from 15 - 30 mGals. At the peninsular neck, where the Nabas Fault is located and alluvium deposits are thickest, values dropped rapidly from 16 down to $-8 \mathrm{mGals}$ in the northern portion, and 16 decreasing to $-10 \mathrm{mGals}$ in the southern portion. Gravity values in the northwestern portion of the Antique Range are low due to the presence of thick alluvium deposits covering the identified fault structure. The highest gravity values in the Antique Range ( 0 - $8 \mathrm{mGals})$ correlate with the presence of ultramafic rocks in the northeastern portion (see also Fig. 2).

A W - E profile of the gravity anomalies at the northern portion of the study area is extracted to further examine the results (Fig. 5b). The chosen profile transects the Nabas Fault and includes gravity stations from both the Buruanga Peninsula and the Antique Range. A corresponding geological cross-section is provided with the profile to identify the lithologies and structures associated with the Bouguer anomaly values. In general, the Buruanga Peninsula exhibits higher Bouguer anomaly values than the Antique Range does. On the western portion of the profile, high gravity anomalies are exhibited by the chert and sandstone units in the Buruanga Peninsula. The denser crystalline limestone unit exhibited higher gravity values than the surrounding chert unit. The gravity values significantly decrease to the east as the Buruanga Peninsula neck is approached. This sudden drop in gravity values is attributed to the presence of the Nabas Fault. In addition, the thick alluvium cover might have also contributed to the low gravity anomalies. East of the Nabas Fault a small peak can be observed in the area where Fragante Formation volcanic rocks outcrop, although their values are still lower than those for the Buruanga Peninsula. Another significant eastward decrease in the gravity anomaly values can be observed as an inferred thrust fault is encountered. Similar to the Nabas Fault, this structure is also covered by thick alluvium deposits. Immediately east of the structure are Lagdo Formation clastics, which display the lowest gravity values in the profile. The peridotite unit of the Antique Ophiolite Complex is thrust over the Lagdo Formation (Zamoras et al. 2008), and is consistently represented by a sudden increase in the gravity values toward the Antique Ophiolite Complex (see also Fig. 2).

\subsection{Seismic Refraction}

The seismic refraction survey results indicate a thick alluvium cover for the Nabas Fault (Fig. 7b). The usual subsurface profile identified from the results consists of two or three layers. The first layer from the surface is interpreted to be loose soil and has a velocity of about $400-600 \mathrm{~m} \mathrm{~s}^{-1}$, with a thickness less than $5 \mathrm{~m}$. The second layer has a velocity of $1500-3000 \mathrm{~m} \mathrm{~s}^{-1}$ and is $20-30 \mathrm{~m}$ in thickness. It is interpreted as broken-up and highly eroded tuff, which is the lithology observed in nearby outcrops. The third layer, if detected by the seismograph, has a velocity greater than $3000 \mathrm{~m} \mathrm{~s}^{-1}$. It is suspected to be the top portion of the more consolidated tuff, although still suspected to be eroded. However, the third layer is not usually shown in the resulting profiles because not all of the shots were able to detect the velocity of this bottom layer. The thickness of the third layer is unknown since the seismic survey penetration depth only reached down to $20 \mathrm{~m}$ or shallower from the surface. It is possible that this eroded volcanic rock layer extends deeper.

Aside from the velocity variation that occurs with depth, a lateral variation for the velocity values can also be observed, especially for the second layer. The highest velocity can be observed in the western survey spreads. In Spreads 1 and 2, the velocities for the second layer range from $2500-2800 \mathrm{~m} \mathrm{~s}^{-1}$. In the eastern portion, in Spread 3, the velocity of the second layer decreased to $1800-2000 \mathrm{~m} \mathrm{~s}^{-1}$. From the rapid change in velocity values, there is a high possibility that a structure gap is present between Spreads 2 and 3. Moving to the east, this lower velocity for Spread 3 was maintained until the 200-m mark, where the velocity suddenly dropped to about $500-800 \mathrm{~m} \mathrm{~s}^{-1}$. These abrupt decreases in velocity are assumed to be caused by the presence of the Nabas Fault and inferred subsurface faults in the area. The geophysical signature of the Nabas Fault appears as a zone of lower velocity values starting from the area between Spread 1 and 2, dropping abruptly again at the 200-m mark in Spread 3 and continuing to decrease to the eastern portion $\left(500-1000 \mathrm{~m} \mathrm{~s}^{-1}\right)$. Lower velocity values could be attributed to the more fractured and shattered properties of fault planes compared to the surrounding area (Yan et al. 2005; Zhigulev and Patrikeev 


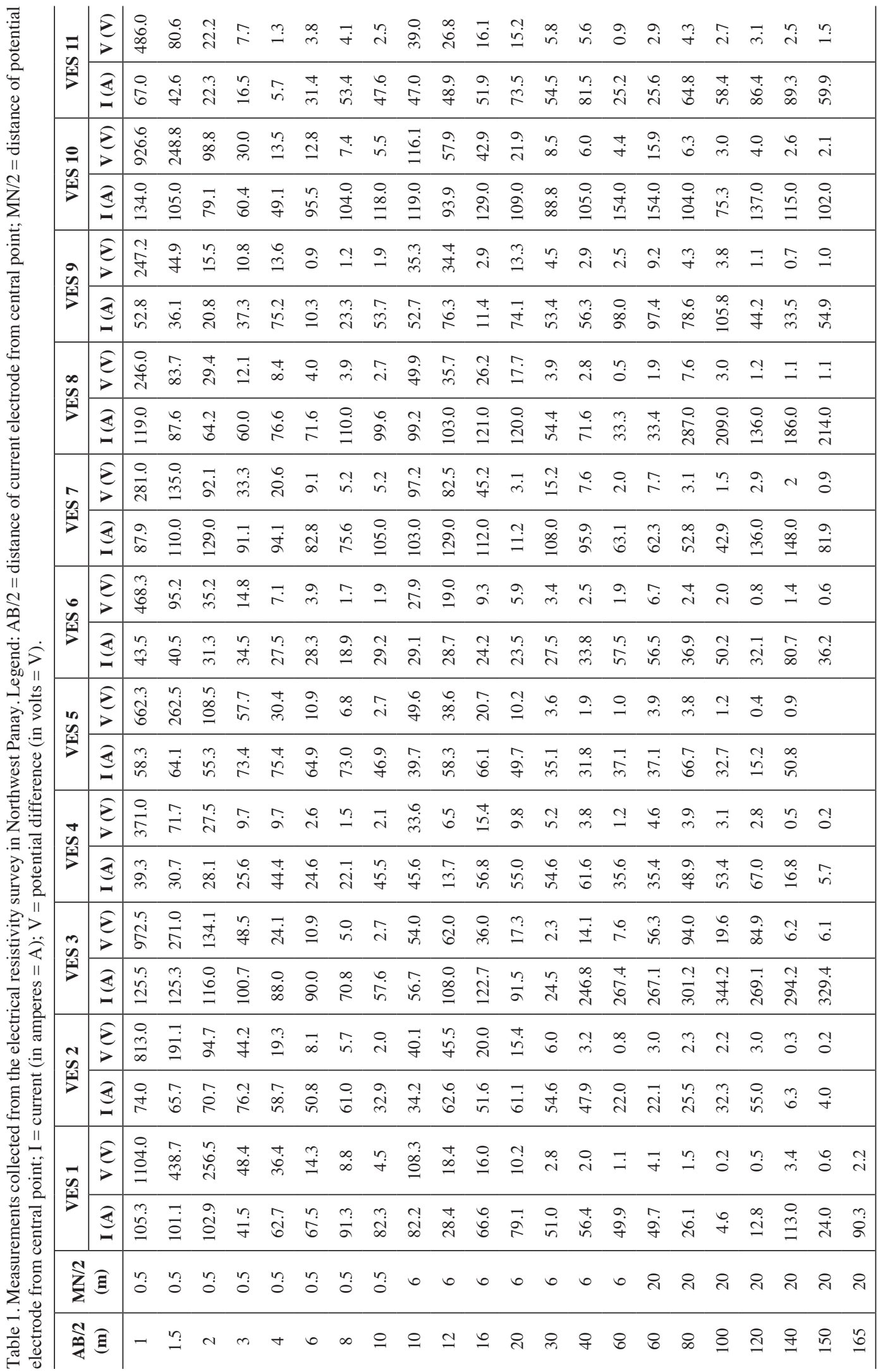


2007). The seismic refraction survey was able to detect the presence of the Nabas Fault on the shallow subsurface. Its geophysical signature is manifested as an area with significantly lower velocity values compared to the western portion of the study area.

\subsection{Electrical Resistivity}

The electrical resistivity survey results indicate two to three subsurface layers for the study area, similar to the seismic refraction survey results (Fig. 7c). The first layer from the surface has resistivity values ranging from $5-15 \Omega-\mathrm{m}$. The thickness of this layer varies from $3-10 \mathrm{~m}$. This layer represents the loose soil similarly identified in the seismic refraction survey, with the lowest velocity values at $400-600 \mathrm{~m} \mathrm{~s}^{-1}$. The second layer has resistivity values of $20-60 \Omega-\mathrm{m}$, showing variable thickness from $20 \mathrm{~m}$ up to more than $40 \mathrm{~m}$. This layer corresponds to the second layer in the seismic refraction survey interpreted to be highly eroded tuff. Similar to the seismic refraction survey results, significant lateral variations exist in the resistivity data. The third layer is prominent in the western portion (VES 1 and 2) and consists of resistivity values as high as $125-186 \Omega-\mathrm{m}$. To the east of VES 2 , an abrupt drop in resistivity values was encountered when the resistivity values decreased to about $10-32 \Omega-\mathrm{m}$. In the seismic refraction results this could be correlated to the change in velocity values between Spread 2 to 3 where the location of the Nabas Fault is postulated. From VES 3 to 7, resistivity values for the second layer are much lower, ranging from 32 - $60 \Omega$-m. Another drop in resistivity measurements occurred in VES 8, where the resistivity value of the second layer dropped to $22 \Omega-\mathrm{m}$. This significant change in resistivity values (VES 8) again coincides with the velocity difference observed in the seismic refraction profile (a distance of $200 \mathrm{~m}$ in Spread 3). The extreme drops in resistivity values suggest the presence of a fault, since the fractured nature of the rocks will result in fluid streaming within the structure (Sharma and Baranwal 2005). East of VES 8, the resistivity values are significantly lower (6 - $45 \Omega-\mathrm{m})$ compared with the western portion. These results are also consistent with the seismic refraction survey. The Nabas Fault was identified by the electrical resistivity investigation as a zone of low resistivity values, especially when compared with the western portion of the area investigated.

\section{DISCUSSION}

\subsection{Subsurface Imaging of a Terrane Boundary: Clues from the Gravity Data}

The gravity method was employed to define the subsurface configuration of Northwest Panay. To accomplish this, forward modeling of the Bouguer anomaly data was carried out from the $\mathrm{E}-\mathrm{W}$ profile in the northern portion (Fig. 8). Several possible scenarios were taken into account during forward modeling to try and explain the higher gravity values from the Buruanga Peninsula than those from the Antique Range. One possibility for the higher gravity values is the older age of the rocks of the Buruanga Peninsula. As sedimentary rocks become older, their densities also significantly increase, especially when compared with much younger sedimentary rocks. The Mesozoic Buruanga Peninsula chert-clastic sequence is possibly denser than the Middle Miocene clastic rocks of the Fragante and Lagdo Formations. However, density measurements for the rock samples in the study area do not show a significant density difference with each other. The average densities of the Jurassic chert $\left(2200 \mathrm{~kg} \mathrm{~m}^{-3}\right)$, limestone $\left(2400 \mathrm{~kg} \mathrm{~m}^{-3}\right)$, and sandstone $\left(2400 \mathrm{~kg} \mathrm{~m}^{-3}\right)$ from the Buruanga Peninsula are not so different from the average density values of the Miocene volcaniclastic rocks $\left(2500 \mathrm{~kg} \mathrm{~m}^{-3}\right)$ and clastic rocks $\left(2100 \mathrm{~kg} \mathrm{~m}^{-3}\right)$ of the Antique Range. Another possible explanation considered in modeling was the presence of a basaltic basement for the Buruanga Peninsula, consistent with an oceanic plate stratigraphic sequence. When this was applied to the model, good correlation between the observed and calculated Bouguer anomaly values was achieved. The resulting model indicates that the alluvium deposits in Northwest Panay are significantly thick (about $100 \mathrm{~m}$ or more), especially in the

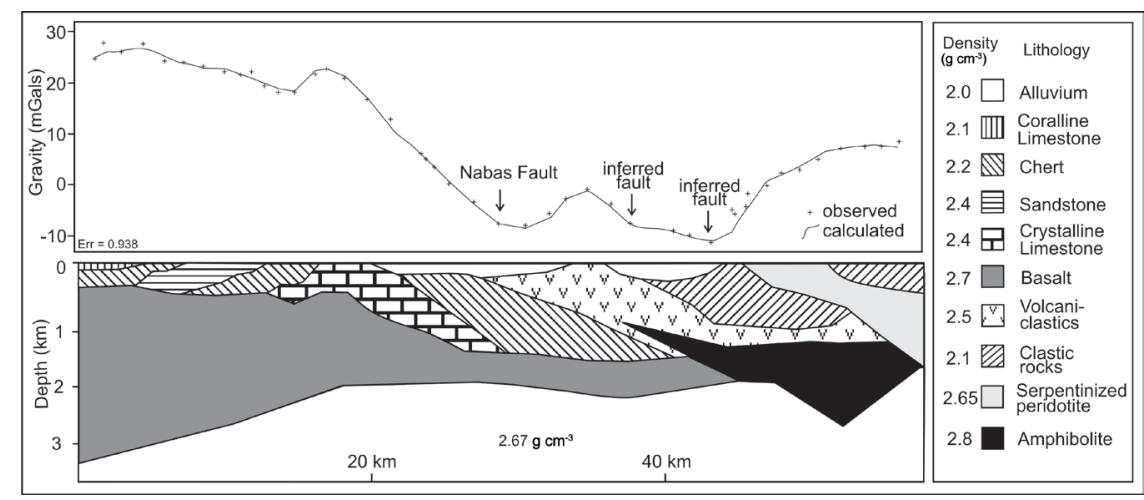

Fig. 8. Optimum forward modeling gravity data results. 
valley where the Nabas Fault is located. The Nabas Fault is modeled to be a thrust fault buried beneath thick alluvium deposits. The Antique Range basement is thrust over the Buruanga Peninsula oceanic plate stratigraphic sequence. The Nabas Fault therefore serves as the terrane boundary for the Buruanga Peninsula and the Antique Range. For the Buruanga Peninsula the chert-clastic-limestone sequence becomes thicker from west to east as the thrust structure is approached. This is consistent with the accretion of sediments toward the terrane boundary, when the collision between the Palawan Micro-continental Block and the Philippine Mobile Belt occurred (Zamoras et al. 2008).

In the eastern portion, the sudden increase in gravity values is interpreted as another fault, wherein the peridotites of the Antique Ophiolite thrust over the clastic units of the Lagdo Formation. The forward modeling results delineated structures related to the collision event.

Available regional gravity anomaly maps were examined for regional comparison. The gravity values from the Bouguer anomaly map of the Philippines (Sonido 1981) indicate that the Buruanga Peninsula and the central northern portion of Panay exhibit relatively higher values ( $\geq 100 \mathrm{mGals}$ ) when compared to the Antique Range (50 - 100 mGals) and rest of Panay island ( $\leq 50 \mathrm{mGals})$. The free-air anomaly profile at latitude $11.78^{\circ} \mathrm{N}$ derived from data by Sandwell and Smith (1997) reveals the regional gravity signature across the Central Philippines (Fig. 9a). The profile shows that the free-air anomaly values for the Northwest Panay is generally lower compared to those of the surrounding areas. In general, the free-air values in offshore areas exhibit a direct correlation with the bathymetry and topography values extracted from the same data set (Fig. 9b), except in the vicinity of onshore areas traversed by the profile. In Northwest Panay the free-air values exhibit a decreasing trend in the area where the Nabas Fault is inferred to be located. In the Northwest Panay onshore area free-air anomaly values are about $25 \mathrm{mGals}$ but gently decrease at longitude $122.0^{\circ} \mathrm{E}$, approaching the boundary between the Buruanga Peninsula and
Antique Range. The free-air anomaly values again exhibit a positive slope from $122.0^{\circ} \mathrm{E}$ to the east, corresponding to the Antique Range, with values ranging from 25 - 50 mGals. The changes in topographic relief in Northwest Panay caused by tectonic structures may account for the variations in the freeair anomaly values for the study area.

The gravity values on Palawan Island are also compared with the results of this study. Palawan Island is considered part of the Palawan Micro-continental Block together with the Buruanga Peninsula. The northern portion of Palawan, including the Calamian Island Group, consists of an oceanic plate stratigraphy similar to that of Buruanga Peninsula (Zamoras and Matsuoka 2001; Zamoras et al. 2008). The Bouguer anomaly values in Northwest Panay appear to have lower values than the anomaly values for Palawan Island (Milsom et al. 2009). In Palawan the regional Bouguer anomaly values range from 50 - $100 \mathrm{mGals,} \mathrm{with}$ some inaccessible areas postulated to have values of around 20 mGals. The gravity values in Palawan decrease from SE to NW, with the higher values associated with ophiolite bodies. Unfortunately, no gravity stations were established on Busuanga Island north of Palawan, where the oceanic plate stratigraphic sequence similar to that of the Buruanga Peninsula is located. Comparing values is therefore not possible. Similar to Northwest Panay, a significant decrease in Bouguer gravity values occurs in the center of Palawan Island, indicating the location of the Ulugan Bay Fault (Milsom et al. 2009). However, Bouguer anomaly values are very similar to those east and west of the Ulugan Bay Fault. The Ulugan Bay Fault is therefore not considered a boundary between the North and South Palawan Blocks (Milsom et al. 2009). Unlike the Ulugan Bay Fault the Nabas Fault could be considered a terrane boundary between the $\mathrm{Bu}$ ruanga Peninsula and the Antique Range because gravity values to the east and west of the Nabas Fault are unique to each other. For Northwest Panay, the gravity method contributed significantly in providing an image of the subsurface terrane boundary affected by the collision. (a)

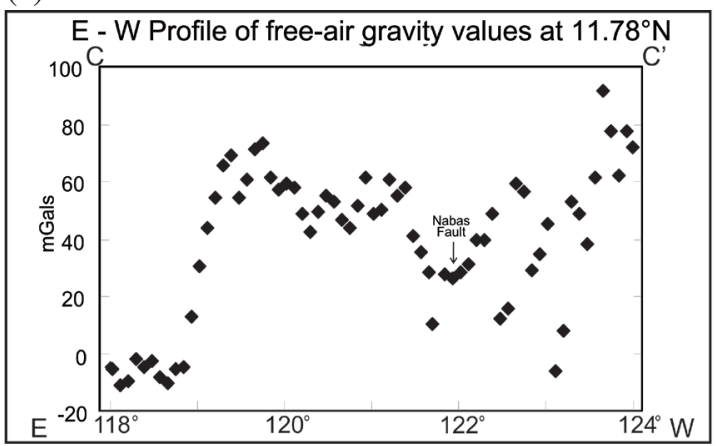

(b)

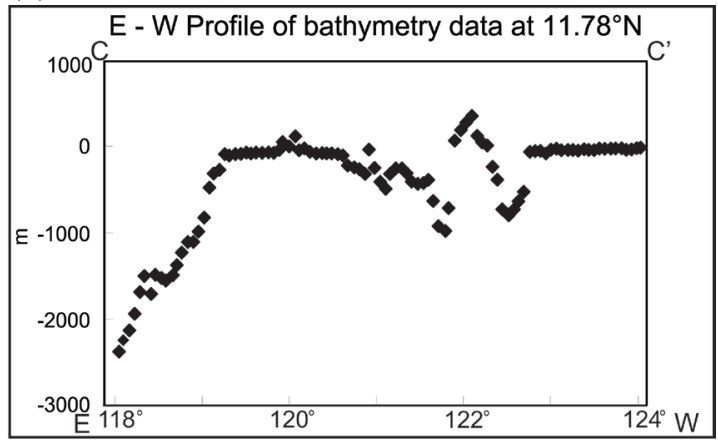

Fig. 9. Regional free-air anomaly profile and bathymetry data at $11.78^{\circ} \mathrm{N}$. (a) A free-air anomaly profile across Central Philippines extracted from the gravity data of Sandwell and Smith (1997). Location of the profile is marked as C - C' in Fig. 4. (b) Bathymetry and topography data profiles at the same location, extracted from the same data set. 


\subsection{Near-Surface Characterization of the Nabas Fault from Seismic Refraction and Electrical Resistivity}

The Nabas Fault was identified by geologic investigation and gravity survey as a buried structure beneath alluvial sediments. The shallow-penetration seismic refraction and electrical resistivity methods were utilized to identify the near-surface geophysical signature of the Nabas Fault. The two geophysical methods were placed alongside each other to constrain the interpretation for both methods.

The seismic refraction survey results coincided with the electrical resistivity survey in identifying three layers for the area investigated. The first layer was interpreted to be loose soil that is $3-10 \mathrm{~m}$ thick based on the low velocity and resistivity values. The second layer was inferred as eroded tuff whereas the third layer was identified as the upper portions of a more consolidated tuff layer, although still eroded. These layers represent the thick alluvium deposits identified in the area. The presence of the Nabas Fault may have enhanced area erosion, producing a thick alluvium deposit and resulting in burial of the structure. Both methods also exhibit lateral variations in values from west to east. A significant decrease in velocity values occurred in the general area where a sudden drop in resistivity values was also detected. These properties are indicative of the subsurface structure and they occur in the inferred location of the Nabas Fault. In addition, the velocity and resistivity values east of the Nabas Fault were much lower compared to those for the western portion. The significantly lower geophysical values in the western portion represent the near-surface geophysical signature of a structure relating to the Nabas Fault. The seismic refraction method results, although with very shallow penetration, point to the presence of a structure. The seismic refraction survey results also coincided with the electrical resistivity method. Both the seismic refraction and electrical resistivity methods identified the Nabas Fault buried beneath the thick alluvium deposits, complementing the gravity modeling results.

\section{CONCLUSIONS}

This study employed geophysical methods to investigate Northwest Panay, a terrane boundary representing the Palawan Micro-continental Block collision with the Philippine Mobile Belt. The gravity survey defined the subsurface configuration of this terrane boundary that separates the $\mathrm{Bu}$ ruanga Peninsula from the Antique Range. It showed the correlation of Bouguer anomaly values to the mapped lithologies, providing a model for the subsurface. The resulting model indicates the presence of a basaltic basement for the Buruanga Peninsula, which is consistent with the oceanic plate stratigraphic sequence identified for this terrane. The results also characterized major structures in Northwest Panay. The Nabas Fault was identified as an east-dipping thrust fault that serves as the terrane boundary between the Buruanga Peninsula and the Antique Range. Additionally, the seismic refraction and electrical resistivity surveys provided near-surface geophysical characterization for the $\mathrm{Na}$ bas Fault. The two shallow-penetration methods were able to detect and confirm the Nabas Fault signature buried beneath alluvial sediments.

This study utilized geophysical tools to constrain the subsurface image of a terrane boundary affected by arc-continent collision. The results from this study will hopefully contribute to the current understanding of subduction-collision processes, especially those involving continent-island arc interactions.

Acknowledgements This study was funded by the Department of Science and Technology (DOST) and monitored by the Philippine Council for Industry and Energy Research and Development, (PCIERD). The National Institute of Geological Sciences, University of the Philippines (UP-NIGS), Mines and Geosciences Bureau Central Office and Regional Office 6, and the local government units in Aklan and Antique are acknowledged for providing logistical support.

\section{REFERENCES}

Abadilla, Q. A., 1931: Geological reconnaissance of Northwestern Capiz Province, Panay, Philippine Islands. Philippine J. Sci., 45, 393-414.

Adepelumi, A. A., M. J. Yi, J. H. Kim, B. D. Ako, and J. S. Son, 2006: Integration of surface geophysical methods for fracture detection in crystalline bedrocks of southwestern Nigeria. Hydrogeol. J., 14, 1284-1306, doi: 10.1007/s10040-006-0051-2. [Link]

Aitchison, J. C., G. L. Clarke, S. Meffre, and D. Cluzel, 1995: Eocene arc-continent collision in New Caledonia and implications for regional southwest Pacific tectonic evolution. Geology, 23, 161-164, doi: 10.1130/00 91-7613(1995)023<0161:EACCIN>2.3.CO;2. [Link]

Armada, L. T., C. B. Dimalanta, G. P. Yumul Jr., and R. A. Tamayo Jr., 2009: Georesistivity signature of crystalline rocks in the Romblon Island Group, Philippines. Philippine J. Sci., 138, 191-204.

Aurelio, M. A, 2000: Tectonics of the Philippines revisited. J. Geol. Soc. Philippines, 55, 119-183.

Aurelio, M. A., E. Barrier, C. Rangin, and C. Müller, 1991: The Philippine Fault in the Late Cenozoic tectonic evolution of the Bondoc-Masbate-N. Leyte area, Central Philippines. J. Southeast Asian Earth Sci., 6, 221-238, doi: 10.1016/0743-9547(91)90069-A. [Link]

Barrier, E., P. Huchon, and M. Aurelio, 1991: Philippine fault: A key for Philippine kinematics. Geology, 19, 3235, doi: 10.1130/0091-7613(1991)019<0032:PFAKFP>2.3.CO;2. [Link]

Bautista, B. C., M. L. P. Bautista, K. Oike, F. T. Wu, and R. 
S. Punongbayan, 2001: A new insight on the geometry of subducting slabs in northern Luzon, Philippines. Tectonophysics, 339, 279-310, doi: 10.1016/S00401951(01)00120-2. [Link]

Besana, G. M., H. Negishi, and M. Ando, 1997: The threedimensional attenuation structures beneath the Philippine archipelago based on seismic intensity data inversion. Earth Planet. Sci. Lett., 151, 1-11, doi: 10.1016/ S0012-821X(97)00112-X. [Link]

Best, M. E. and J. B. Boniwell, 1989: A Geophysical Handbook for Geologists, Vol. 41, Canadian Institute of Mining and Metallurgy, Canada, $181 \mathrm{pp}$.

Brown, D., P. Spadea, V. Puchkov, J. Alvarez-Marron, R. Herrington, A. P. Willner, R. Hetzel, Y. Gorozhanina, and C. Juhlin, 2006: Arc-continent collision in the Southern Urals. Earth-Sci. Rev., 79, 261-287, doi: 10.1016/j.earscirev.2006.08.003. [Link]

Byrne, T. B. and C. S. Liu, 2002: Geology and Geophysics of an Arc-Continent Collision, Taiwan, Vol. 358, Geological Society of America, Boulder, Colorado, $211 \mathrm{pp}$.

Chi, W. C., D. L. Reed, G. Moore, T. Nguyen, C. S. Liu, and N. Lundberg, 2003: Tectonic wedging along the rear of the offshore Taiwan accretionary prism. Tectonophysics, 374, 199-217, doi: 10.1016/j.tecto.2003.08.004. [Link]

Condie, K. C., 1997: Plate Tectonics and Crustal Evolution, $4^{\text {th }}$ edition, Butterworth-Heinemann, United Kingdom, $288 \mathrm{pp}$.

Dimalanta, C. B. and G. P. Yumul Jr., 2004: Crustal thickening in an active margin setting (Philippines): The whys and the hows. Episodes, 27, 260-264.

Dutta, S., N. S. Krishnamurthy, T. Arora, V. A. Rao, S. Ahmed, and J. M. Baltassat, 2006: Localization of water bearing fractured zones in a hard rock area using integrated geophysical techniques in Andhra Pradesh, India. Hydrogeol.J., 14, 760-766 doi: 10.1007/s10040005-0460-7. [Link]

Eaton, D. W. and F. Darbyshire, 2010: Lithospheric architecture and tectonic evolution of the Hudson Bay region. Tectonophysics, 480, 1-22, doi: 10.1016/j.tecto.2009.09.006. [Link]

English, J. M. and S. T. Johnston, 2005: Collisional orogenesis in the northern Canadian Cordillera: Implications for Cordilleran crustal structure, ophiolite emplacement, continental growth, and the terrane hypothesis. Earth Planet. Sci. Lett., 232, 333-344, doi: 10.1016/j. eps1.2005.01.025. [Link]

Francisco, F. U., 1956: The pre-Tertiary rocks of Buruanga Peninsula, Panay Island, Philippines. Proc. Pac. Sci. Congr., 2, 482-494.

Franco, H. and D. Abbott, 1999: Gravity signatures of terrane accretion. Lithos, 46, 5-15, doi: 10.1016/S00244937(98)00060-7. [Link]

Gabo, J. A. S., 2009: Subsurface investigation of Buruanga
Peninsula, Northwest Panay, Philippines: Characterizing the collision zone using gravity, seismic refraction and electrical resistivity methods. Master Thesis, University of the Philippines, Philippines.

Gabo, J. A. S., C. B. Dimalanta, M. G. S. Asio, K. L. Queaño, G. P. Yumul Jr., and A. Imai, 2009: Geology and geochemistry of the clastic sequences from Northwestern Panay (Philippines): Implications for provenance and geotectonic setting. Tectonophysics, 479, 111-119, doi: 10.1016/j.tecto.2009.02.004. [Link]

Ganerød, G. V., J. S. Rønning, E. Dalsegg, H. Elvebakk, K. Holmøy, B. Nilsen, and A. Braathen, 2006: Comparison of geophysical methods for sub-surface mapping of faults and fracture zones in a section of the Viggja road tunnel, Norway. B. Eng. Geol. Environ., 65, 231243, doi: 10.1007/s10064-006-0041-6. [Link]

Hayes, D. E. and S. D. Lewis, 1984: A geophysical study of the Manila Trench, Luzon, Philippines: 1. Crustal structure, gravity, and regional tectonic evolution. J. Geophys. Res., 89, 9171-9195, doi: 10.1029/ JB089iB11p09171. [Link]

Heidbach, O., M. Tingay, A. Barth, J. Reinecker, D. Kurfeb, and B. Müller, 2008: The World Stress Map Database Release, doi: 10.1594/GFZ.WSM.Rel2008. [Link]

Holloway, N. H., 1982: North Palawan Block, Philippines; its relation to Asian mainland and role in evolution of South China Sea. AAPG Bull., 66, 1355-1383.

Hsu, S. K., Y. C. Yeh, W. B. Doo, and C. H. Tsai, 2004: New bathymetry and magnetic lineations identifications in the northernmost South China Sea and their tectonic implications. Mar. Geophys. Res., 25, 29-44, doi: 10.1007/s11001-005-0731-7. [Link]

Japan International Cooperation Agency, Metal Mining Agency of Japan, Mines and Geosciences Bureau (JICA-MMAJ), 1988: The mineral exploration mineral deposits and tectonics of two contrasting geologic environments in the Republic of Philippines. Consolidated Report on Masbate, Panay and Romblon Area, 1-12.

King, M. S. and S. M. Barr, 2004: Magnetic and gravity models across terrane boundaries in southern New Brunswick, Canada. Can. J. Earth Sci., 41, 1027-1047, doi: 10.1139/e04-046. [Link]

Largueche,F.Z. B., 2006: Estimating soil contamination with Kriging interpolation method. Am.J. Appl. Sci.,3, 18941898, doi: 10.3844/ajassp.2006.1894.1898. [Link]

Louis, I. F., D. Raftopoulos, I. Goulis, and F. I. Louis, 2002: Geophysical imaging of faults and fault zones in the urban complex of Ano Liosia Neogene basin, Greece: Synthetic simulation approach and field investigations. J. Electr. Electronics Eng., 269-285.

McCabe, R., J. Almasco, and W. Diegor, 1982: Geologic and paleomagnetic evidence for a possible Miocene collision in western Panay, central Philippines. Geology, 10, 325-329, doi: 10.1130/0091-7613(1982) 
10<325:GAPEFA $>2.0 . C O ; 2$. [Link]

McCabe, R., J. N. Almasco, and G. Yumul, 1985: Terranes of the central Philippines. In: Howell, D. G. (Ed.), Tectonostratigraphic Terranes of the Circum-Pacific Region, Earth Science Series, No. 1, CircumPacific Council for Energy and Mineral Resources, 421-436.

Meffre, S. and A. J. Crawford, 2001: Collision tectonics in the New Hebrides arc (Vanuatu). Isl. Arc, 10, 33-50, doi: 10.1046/j.1440-1738.2001.00292.x. [Link]

Milsom, J., 1996: Field Geophysics, $2^{\text {nd }}$ edition, The Geological Field Guide Series, Vol. 21, Wiley, 187 pp.

Milsom, J., J. Barretto, N. Aguda, D. Bringas, R. Ho, and J. Aitchison, 2009: The gravity fields of Palawan and New Caledonia: Insights into the subsurface geometries of ophiolites. J. Geol. Soc., 166, 985-988, doi: 10.1144/0016-76492009-067. [Link]

Mines and Geosciences Bureau, 2004: Geology and Mineral Resources of the Philippines 1, Department of Environment and Natural Resources, Quezon City, 224-238.

OuterTC, 2009: Plouff's Terrane Correction Code. Available at http://geopotential.com/docs/OuterTC/OuterTC.shtml.

Pubellier, M. and P. R. Cobbold, 1996: Analogue models for the transpressional docking of volcanic arcs in the Western Pacific. Tectonophysics, 253, 33-52, doi: 10.1016/0040-1951(95)00034-8. [Link]

Ramos, N. T., C. B. Dimalanta, G. M. Besana, R. A. Tamayo Jr., G. P. Yumul Jr. and V. B. Maglambayan, 2005: Seismotectonic reactions to the arc-continent convergence in central Philippines. Resour. Geol., 55, 199206, doi: 10.1111/j.1751-3928.2005.tb00241.x. [Link]

Rangin, C. and E. A. Silver, 1991: Neogene tectonic evolution of the Celebes-Sulu basins: New insights from Leg 124 drilling. Proc. Ocean Drill. Program. Sci. Results, 124, 51-63, doi: 10.2973/odp.proc.sr.124.122.1991. [Link]

Rangin, C., C. Mueller, and H. Porth, 1989: Neogene geodynamic evolution of the Visayan region. Geol. Jahrb. Reihe B, 70, 7-27.

Rangin, C., J. F. Stephan, J. Butterlin, H. Bellon, C. Muller, J. Chorowicz, and D. Baladad, 1991: Collision néogène d'arcs volcaniques dans le centre des Philippines: Stratigraphie et structure de la chaîne d'Antique (île de Panay). B. Soc. Geol. Fr., 162, 465-477.

Sandwell, D. T. and W. H. F. Smith, 1997: Marine gravity anomaly from Geosat and ERS 1 satellite altimetry. J. Geophys. Res., 102, 10039-10054, doi: 10.1029/96JB03223. [Link]

Sarewitz, D. R. and D. E. Karig, 1986: Stratigraphic framework of western Mindoro island, Philippines. Phil. Geol., 40, 3-51.

Scalabrino, B., J. F. Ritz, and Y. Lagabrielle, 2011: Relief inversion triggered by subduction of an active spreading ridge: Evidence from glacial morphology in Central
Patagonia. Terr. Nova, 23, 63-69, doi: 10.1111/j.13653121.2010.00981.x. [Link]

Seaton, W. J. and T. J. Burbey, 2002: Evaluation of twodimensional resistivity methods in a fractured crystalline-rock terrane. J. Appl. Geophys., 51, 21-41, doi: 10.1016/S0926-9851(02)00212-4. [Link]

Sharma, S. P. and V. C. Baranwal, 2005: Delineation of groundwater-bearing fracture zones in a hard rock area integrating very low frequency electromagnetic and resistivity data. J. Appl. Geophys., 57, 155-166, doi: 10.1016/j.jappgeo.2004.10.003. [Link]

Sonido, E. P., 1981: The state of gravity works in the Philippines. J. Geol. Soc., 35, 37-50.

Suresh, T. S., C. Naganna, and G. Srinivas, 1992: Exploration for groundwater in Hemavathy river basin, Karnataka: Using resistivity techniques. J. Indian Acad. Geosci., 35, 25-30.

Tamayo, R. A., G. P. Yumul Jr., R. C. Maury, M. Polvé, J. Cotten, and M. Bohn, 2001: Petrochemical investigation of the Antique Ophiolite (Philippines): Implications on volcanogenic massive sulfide and podiform chromitite deposits. Resour. Geol., 51, 145-164, doi: 10.1111/j.1751-3928.2001.tb00088.x. [Link]

Taylor, B. and D. E. Hayes, 1980: The tectonic evolution of the South China Basin. In: Hayes, D. E. (Ed.), The Tectonic and Geologic Evolution of Southeast Asian Seas and Islands, American Geophysical Union, Washington, D. C., 89-104, doi: 10.1029/GM023p0089. [Link]

Telford, W. M., 1976: Applied Geophysics, Cambridge University Press, Cambridge, 860 pp.

Wakita, K. and I. Metcalfe, 2005: Ocean Plate Stratigraphy in East and Southeast Asia. J. Asian Earth Sci., 24, 679-702, doi: 10.1016/j.jseaes.2004.04.004. [Link]

Walia, M., T. F. Yang, U. Knittel, T. K. Liu, C. H. Lo, S. L. Chung, L. S. Teng, C. B. Dimalanta, G. P. Yumul Jr., and W. M. Yuan, 2013: Cenozoic tectonics in the Buruanga Peninsula, Panay Island, Central Philippines, as constrained by $\mathrm{U}-\mathrm{Pb},{ }^{40} \mathrm{Ar} /{ }^{39} \mathrm{Ar}$ and fission track thermochronometers. Tectonophysics, 582, 205-220, doi: 10.1016/j.tecto.2012.10.002. [Link]

Wang, C. Y., Y. H. Lee, and Y. Y. Hu, 2005: Re-evaluating an active fault in a major computer-manufacturing area in northern Taiwan using ' 1 sec' shallow reflection seismics. Geophys. Res. Lett., 32, L08313, doi: 10.1029/2005GL022344. [Link]

White, D. J., M. D. Thomas, A. G. Jones, J. Hope, B. Németh, and Z. Hajnal, 2005: Geophysical transect across a Paleoproterozoic continent-continent collision zone: The Trans-Hudson Orogen. Can. J. Earth Sci., 42, 385-402, doi: 10.1139/e05-002. [Link]

Yan, Z., R. W. Clayton, and J. Saleeby, 2005: Seismic refraction evidence for steep faults cutting highly attenuated continental basement in the central Transverse ranges, California. Geophys. J. Int., 160, 651-666, doi: 
10.1111/j.1365-246X.2005.02506.x. [Link]

Yumul, G. P., Jr., C. B. Dimalanta, R. A. Tamayo Jr., and R. C. Maury, 2003: Collision, subduction and accretion events in the Philippines: A synthesis. Isl. Arc, 12, 77-91, doi: 10.1046/j.1440-1738.2003.00382.x. [Link]

Yumul, G. P., Jr., C. B. Dimalanta, and R. A. Tamayo Jr., 2005: Indenter-tectonics in the Philippines: Example from the Palawan Microcontinental Block - Philippine Mobile Belt Collision. Resour. Geol., 55, 189-198, doi: 10.1111/j.1751-3928.2005.tb00240.x. [Link]

Yumul, G. P., Jr., C. B. Dimalanta, E. J. Marquez, and K. L. Queaño, 2009: Onland signatures of the Palawan microcontinental block and Philippine mobile belt collision and crustal growth process: A review. J. Asian Earth Sci., 34, 610-623, doi: 10.1016/j.jseaes.2008.10.002. [Link]

Zamoras, L. R. and A. Matsuoka, 2001: Malampaya Sound Group: A Jurassic-Early Cretaceous accretionary com- plex in Busuanga Island, North Palawan Block (Philippines). J.Geol.Soc. Japan, 107, 316-336, doi: 10.5575/ geosoc.107.316. [Link]

Zamoras, L. R. and A. Matsuoka, 2004: Accretion and postaccretion tectonics of the Calamian Islands, North Palawan block, Philippines. Isl. Arc, 13, 506-519, doi: 10.1111/j.1440-1738.2004.00443.x. [Link]

Zamoras, L. R., M. G. A. Montes, K. L. Queaño, E. J. Marquez, C. B. Dimalanta, J. A. S. Gabo, and G. P. Yumul Jr., 2008: Buruanga peninsula and Antique Range: Two contrasting terranes in Northwest Panay, Philippines featuring an arc-continent collision zone. Isl. Arc, 17, 443-457, doi: 10.1111/j.1440-1738.2008.00645.x. [Link]

Zhigulev, V. V. and V. N. Patrikeev, 2007: Shallow seismic refraction analysis: Application to studying the active North Sakhalin fault. Russ. J. Pac. Geol., 1, 15-21, doi: 10.1134/S1819714007010034. [Link] 